\title{
Pemodelan Pertumbuhan Ekonomi Provinsi Sulawesi Selatan dengan Menggunakan Regresi Data Panel
}

\author{
Misriani Suardin, M. Nadjib Bustan, \& Ansari Saleh Ahmar* \\ Program Studi Statistika, Fakultas Matematika dan Ilmu Pengetahuan Alam, Universitas Negeri Makassar, Indonesia
}

Keywords: Regression, resampling, bootstrap, jackknife

\begin{abstract}
:
Economic growth is a process for change the economic condition a country or regional by continuously for the better condition as long as definite period. Economic growth in South Sulawesi for 2013-2016 have up and down because many factors have influence it. Like jobless, human capital index, regional revenue, expenditure, and total population. This research was conducted to determine the factors that influence economic growth in South Sulawesi by using data panel regression methods. Panel data regression is a regression by using panel data. Panel data is a statistics analysis method that combines between time series data and cross section data. The result indicates that the result if the regression analysis on the $\alpha=5 \%$ show that the best panel data regression model is random effect model and human capital index variable have significant effect on economic growth with probability value about 0,0227 . Meanwhile, jobless, regional revenue, expenditure, and total population no significant.
\end{abstract}

\section{Pendahuluan}

Pertumbuhan Ekonomi merupakan proses perubahan kondisi perekonomian suatu negara atau daerah secara berkesinambungan menuju keadaan yang lebih baik selama periode waktu tertentu. Suatu perekonomian dikatakan mengalami suatu perubahan akan perkembangannya apabila tingkat kegiatan ekonomi lebih tinggi daripada yang dicapai pada masa sebelumnya.

Pertumbuhan ekonomi ialah proses kenaikan output perkapita yang terus menerus dalam jangka panjang (Sukirno, 2004). Pertumbuhan ekonomi tersebut merupakan salah satu indikator keberhasilan pembangunan. Dengan demikian makin tingginya pertumbuhan ekonomi biasanya makin tinggi pula kesejahteraan masyarakat, meskipun terdapat indikator yang lain yaitu distribusi pendapatan. Masalah pertumbuhan ekonomi di suatu daerah tergantung dari banyak faktor, salah satunya adalah kebijakan pemerintah itu sendiri.

Provinsi Sulawesi Selatan merupakan salah satu provinsi di Indonesia yang signifikan mempengaruhi pertumbuhan ekonomi nasional. Pertumbuhan ekonomi Sulawesi Selatan pada 2013 sebesar 7,69 \% menduduki peringkat kedua tertinggi di pulau Sulawesi setelah Sulawesi Tengah, dan lebih tinggi dibandingkan Sulawesi Barat dan Sulawesi Utara. Pada tahun 2016 pertumbuhan ekonomi Sulawesi Selatan mengalami penurunan sebesar 7,43\%, masih lebih rendah dibandingkan Sulawesi Tengah yang sebesar 9,98\%, dan lebih tinggi dibandingkan beberapa provinsi lainnya di pulau Sulawesi. Banyak faktor yang mempengarui pertumbuhan ekonomi antara lain: tingkat pengangguran, indeks pembangunan manusia, pendapatan asli daerah, pengeluaran pemerintah, dan jumlah penduduk. Sehingga untuk mengetahui faktor-faktor apa saja yang berpengaruh terhadap pertumbuhan ekonomi di Provinsi Sulawesi Selatan maka teknik analisis yang digunakan adalah analisis regresi ganda untuk data panel. Dengan teknik analisis kita

\footnotetext{
* Corresponding author.

E-mail address: ansarisaleh@unm.ac.id
} 
melakukan pengecekan asumsi dan pemilihan model terbaik dan kemudian dapat mengetahui faktor-faktor apa yang mempengaruhi pertumbuhan ekonomi di Provinsi Sulawesi Selatan.

\section{Tinjauan Pustaka}

\subsection{Data dan Jenis-Jenis data}

Data adalah bahan mentah yang perlu diolah sehingga menghasilkan infomasi atau keterangan, baik kuantitatif maupun kualitatif yang menunjukkan fakta. Berdasarkan waktu pengumpulannya, data dibedakan menjadi tiga yaitu data cross section (data silang), data time series (runtun waktu), dan data panel. Data cross- sectional adalah data yang dikumpulkan dengan mengamati banyak subjek (seperti individu, perusahaan, atau negara/wilayah) pada waktu yang sama, data cross-sectional biasanya terdiri dari membandingkan perbedaan antara subjek (Jirata, 2014). Data time series adalah adalah data pengamatan yang dikumpulkan melalui pengukuran berulang dari waktu ke waktu, jumlah yang mewakili nilai yang diambil oleh variabel selama periode seperti bulan, kuartal, atau tahun (Jirata, 2014). Data panel mengacu pada pengumpulan data pengamatan pada banyak subjek selama beberapa periode waktu (Baltagi, 2005).

\subsection{Analisis Regresi Data Panel}

Analisis regresi data panel adalah salah satu metode statistik yang digunakan untuk melihat pengaruh beberapa peubah prediktor terhadap satu peubah respon dengan struktur data berupa data panel. Secara umum, persamaan model regtesi data panel sebagai berikut:

$$
Y_{i t}=\beta_{0 i t}+\sum_{k=1}^{n} \beta_{k} X_{k i t}+e_{i t}
$$

dengan:

$$
\begin{aligned}
& Y_{i t}=\text { Unit } \text { cross section ke- } i \text { periode waktu ke- } t . \\
& \beta_{0}=\text { Intercept } \\
& \beta_{k}=\text { Koefisien slope untuk semua unit. } \\
& X_{i t}=\text { Variabel prediktor untuk unit cross section ke-i periode waktu ke- } t . \\
& e_{i t}=\text { Galat atau komponen } \text { error pada unit observasi ke- } i \text { dan waktu ke- } t . \\
& i \quad=\text { Unit } \text { cross section }(1,2, \ldots, \mathrm{N}) . \\
& t \quad=\text { Unit } \text { time series }(1,2, \ldots, \mathrm{T}) . \\
& \mathrm{k}=\text { Jumlah variabel prediktor }(1, \ldots, \mathrm{n}) .
\end{aligned}
$$

\subsection{Model Regresi Data panel}

\subsubsection{Common Effect Model}

Common Effect Model seluruh data digabungkan baik data cross section maupun data time series, tanpa memperdulikan waktu dan tempat penelitian. Pada metode ini diasumsikan bahwa nilai intercept masing- masing variabel adalah sama, begitu pula slope koefisien untuk semua unit cross section dan time series (Apriliawan dkk., 2013). Persamaan common effect model dapat dinyatakan sebagai berikut:

$$
Y_{i t}=\beta_{0}+\sum_{k=1}^{n} \beta_{k} X_{k i t}+e_{i t}
$$

dengan:

$Y_{i t}=$ Variabel respon pada unit observasi ke-i dan waktu ke-t.

$X_{k i t}=$ Variabel prediktor pada unit observasi ke-i dan waktu ke-t.

$\beta_{k}=$ Koefisien slope. 


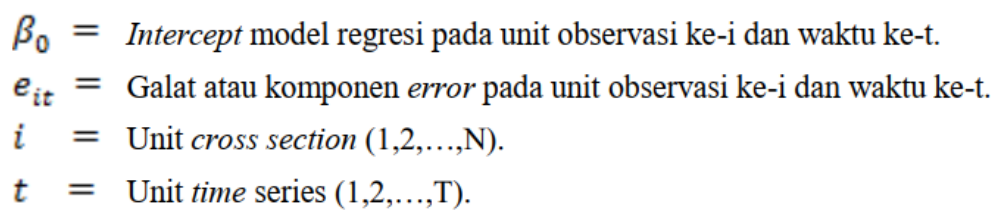

\subsubsection{Fixed Effect Model}

Fixed effect model adalah metode regresi yang mengestimasi data panel dengan menambahkan variabel boneka (Pangestika, 2015). Model ini mengasumsi bahwa terdapat efek yang berbeda antar individu. Perbedaan itu dapat diakomodasi melalui perbedaan pada intersepnya. Oleh karena itu, dalam fixed effect model setiap individu merupakan parameter yang tidak diketahui dan akan diestimasi dengan menggunakan teknik variabel boneka sehingga metode ini seringkali disebut dengan Least Square Dummy Variable. Persamaan fixed effect model dapat dinyatakan sebagai berikut:

$$
Y_{i t}=\beta_{0_{i t}}+\sum_{k=1}^{n} \beta_{k} X_{k i t}+e_{i t}
$$

dengan:

$$
\begin{aligned}
& Y_{i t}=\text { Variabel respon pada unit observasi ke- } i \text { dan waktu ke-t. } \\
& \beta_{0_{i t}}=\text { Intercept model regresi unit observasi ke- } i \text { dan waktu ke- } t \text {. } \\
& \beta_{k}=\text { Koefisien slope. } \\
& X_{k i t}=\text { Variabel prediktor pada unit observasi ke- } i \text { dan waktu ke- } t \text {. } \\
& e_{i t}=\text { Galat atau komponen error pada unit observasi ke- } i \text { dan waktu ke- } t \text {. } \\
& i=\text { Unit cross section }(1,2, \ldots, \mathrm{N}) \text {. } \\
& t=\text { Unit time series }(1,2, \ldots, \mathrm{T}) \text {. } \\
& k=\text { Jumlah variabel prediktor }(1,2, \ldots, \mathrm{n}) \text {. }
\end{aligned}
$$

\subsubsection{Random Effect Model}

Random effect model akan mengestimasi data panel dimana variabel gangguan mungkin saling berhubungan antar waktu atau antar individu. Pada fixed effect model bisa menimbulkan masalah, salah satunya adalah berkurangnya nilai derajat kebebasan (degree of freedom) yang berakibat pada pengurangan efisiensi parameter, sehingga muncul random effect model yang bertujuan untuk mengatasi masalah yang ditimbulkan oleh fixed effect model (Rizki, 2011). Persamaan random effect model dinyatakan sebagai berikut:

$$
Y_{i t}=\beta_{0}+\sum_{k=1}^{n} \beta_{k} X_{k i t}+\mu_{i}+e_{i t}
$$

dengan:

$Y_{i t}=$ Variabel respon pada unit observasi ke-i dan waktu ke-t.

$\beta_{0}=$ Intercept model regresi pada unit observasi ke- $i$ dan waktu ke- $t$.

$\beta_{k}=$ Koefisien slope.

$X_{i t}=$ Variabel prediktor pada unit observasi ke- $i$ dan waktu ke- $t$.

$\mu_{i}=$ Galat atau error pada unit observasi ke- $i$.

$e_{i t}=$ Galat atau komponen error pada unit observasi ke- $i$ dan waktu ke- $t$.

$i=$ Unit cross section $(1,2, \ldots, \mathrm{N})$.

$t=$ Unit time series $(1,2, \ldots, \mathrm{T})$.

$k=$ Jumlah variabel prediktor $(1,2, \ldots, \mathrm{n})$. 


\subsubsection{Pemilihan Model Regresi Data Panel}

Pemilihan model estimasi regresi data panel ini bertujuan untuk memilih model terbaik yang tepat dan sesuai dari ketiga model regresi antara lain Common Effect Model, Fixed Effect Model, Random Effect Model. Dalam pemilihan model estimasi regresi data panel terbaik maka selanjutnya dilakukan uji sebagai berikut:

a) Uji Chow (Chow Test)

Uji Chow merupakan uji untuk membandingkan model common effect dengan fixed effect (Pangestika, 2015).

Adapun hipotesis dari chow test yaitu:

$H_{0}$ : Model yang digunakan common effect model

$H_{1}$ : Model yang digunakan fixed effect model

Menurut Sukartika (2009) ersamaan dari chow test adalah sebagai berikut:

$$
\text { Chow }=\frac{[\text { RRS }- \text { URSS }] /(n-1)}{\text { URSS } /(n T-n-K)}
$$

dimana:

$$
\begin{aligned}
& \text { RRS }=\sum e_{i}^{2} \\
& \text { URSS }=\sum e_{J}^{2}
\end{aligned}
$$

Keterangan:

$$
\begin{aligned}
n= & \text { Jumlah individu (cross } \\
T= & \text { section). Jumlah periode waktu } \\
K= & \text { (time series). Jumlah variabel } \\
e_{i}^{2}= & \text { prediktor. } \\
e_{J}^{2}= & \text { Jumlah } \text { error } \text { kuadrat dari estimasi data panel common } \\
& \text { effect. Jumlah } \text { error kuadrat dari estimasi data panel } \\
& \text { fixed effect. }
\end{aligned}
$$

Jika nilai $C$ how $>F_{(n-1),(n T-n-K)}$ atau $p$-value $<$, maka $H_{0}$ ditolak, yang artinya model fixed effect yang terbaik. Ketika model yang terpilih adalah fixed effect maka dilanjutkan dengan uji Hausman.

b) Uji Hausman (Hausman Test)

Uji Hausman digunakan untuk memilih model terbaik antara fixed effect model dengan random effect model yang akan digunakan. Hipotesis uji Hausman yaitu:

$$
\begin{array}{rll}
H_{0} & : & \text { Model yang digunakan random effect model } \\
H_{1} & : & \text { Model yang digunakan fixed effect model }
\end{array}
$$

Persamaan uji Hausman, sebagai berikut:

$$
X^{2}(K)=(b-\beta)^{\prime}[\operatorname{Var}(b-\beta)]^{-1}(b-\beta)
$$

Keterangan:

$$
\begin{aligned}
& b=\text { Koefisien random effect } \\
& \beta=\text { Koefisien fixed effect }
\end{aligned}
$$

Statistik Hausman menyebar chi-square, jika nilai $\mathrm{X}^{2}$ hasil pengujian lebih besar dari $X_{(K, \alpha)}^{2}(\mathrm{~K}=$ jumlah variabel prediktor) atau p-value $<\alpha$, maka cukup bukti untuk melakukan penolakan terhadap begitu pula sebaliknya. 


\subsubsection{Pengujian Signifikansi Parameter}

Uji signifikansi parameter bertujuan untuk menguji apakah koefisien regresi yang diperoleh signifikan atau tidak (Pangestika, 2015). Dikatakan signifikan apabila nilai koefisien regresi secara statistik sama dengan nol. Apabila koefisien regresi tidak sama dengan nol, maka dapat dikatakan bahwa variabel prediktor tidak cukup bukti berpengaruh terhadap variabel respon (Apriliawan dkk, 2013). Oleh karena itu, maka semua nilai koefisien regresi harus di uji menggunakan dua uji antara lain Uji Keseluruhan (Uji F) dan Uji Parsial (Uji T).

a) Uji Keseluruhan (Uji F)

Uji Keseluruhan (Uji F) bertujuan untuk mengetahui pengaruh semua variabel prediktor terhadap variabel respon. Hipotesis dalam uji F sebagai berikut (Prasanti dkk, 2015):

$$
\begin{aligned}
& H_{0}: \beta_{1}=\beta_{2}=\beta_{3}=\cdots=\beta_{k}=0 \\
& H_{1}: \beta_{k} \neq 0 \text { dengan } k=1,2, \ldots, n
\end{aligned}
$$

Persamaan uji F sebagai berikut:

Keterangan:

$$
F_{\text {hitung }}=\frac{R^{2} /(n+K-1)}{\left(1-R^{2}\right) /(n T-n-K)}
$$

$$
\begin{aligned}
& R^{2}=\text { Koefisien Determinasi. } \\
& n=\text { Jumlah (cross section). } \\
& K=\text { Jumlah variabel prediktor. } \\
& \mathrm{T}=\text { Jumlah (time series) }
\end{aligned}
$$

Jika $F_{\text {hitung }}$ lebih besar dari $F_{\text {tabel }}$, maka $H_{0}$ ditolak. Artinya variabel prediktor tidak mempunyai pengaruh secara keseluruhan terhadap variabel respon, demikian pula sebaliknya.

b) Uji Parsial (Uji T)

Uji Parsial (Uji T) bertujuan untuk mengetahui signifikansi variabel prediktor secara individu terhadap variabel respon. Hipotesis dalan Uji T sebagai berikut (Prasanti dkk, 2015):

$$
\begin{aligned}
& H_{0}: \beta_{j}=0 \\
& H_{1}: \beta_{j} \neq 0
\end{aligned}
$$

Persamaan Uji T sebagai berikut:

$$
t=\frac{b_{j}}{\sin \left(b_{j}\right)}
$$

Kriteria uji yang digunakan adalah jika $\left|t_{\text {hitung }}\right|>t_{\text {tabel }\left(t_{\alpha / 2}, n-k\right)}$, maka tolak $\mathrm{H}_{0}$ yang menandakan bahwa terdapat pengaruh secara individu variabel prediktor terhadap variabel respon, begitu pula sebaliknya.

\subsubsection{Uji Asumsi Regresi Data Panel}

Model regresi data panel dapat dikatakan sebagai model yang baik jika memenuhi kriteria Best, Linear, Unbiased, dan Estimator (BLUE). BLUE dapat dicapai bila model tersebut memenuhi asumsi klasik berikut:

a) Uji Normalitas

Uji normalitas bertujuan untuk menguji apakah nilai error dalam persamaan regresi berdistribusi normal atau tidak (Rahmadeni, 2017). Uji normalitas residual secara formal dapat dideteksi dari metode yang dikembangkan oleh Kolmogorof Smirnov dengan hipotesis sebagai berikut:

$$
\begin{array}{ll}
H_{0}: \varepsilon_{i}=0 & \text { data } \text { error berdistribusi normal } \\
H_{1}: \varepsilon_{i} \neq 0 & \text { data } \text { error tidak berdistribusi normal }
\end{array}
$$

Kriteria uji : $\quad p$-value $>\alpha$ maka $H_{0}$ diterima asumsi kenormalan terpenuhi begitu pula sebaliknya. 
b) Uji Multikolinearitas

Uji Multikolinearitas bertujuan untuk melihat ada atau tidaknya korelasi antara variabel-variabel prediktor. Dalam memprediksi ada atau tidaknya multikolinearitas dalam suatu data dapat dilihat nilai tolerance dan VIF. Besarnya nilai VIF dapat dicari dengan rumus:

$$
V I F_{j}=\frac{1}{\text { tolerance }}=\frac{1}{1-R_{j}^{2}}
$$

Dengan $R_{j}^{2}$ adalah nilai koefisien determinasi antara variabel respon ke-j dengan variabel prediktor sisanya (k- 1). Jika nilai VIF > 10, maka secara signifikan dapat simpulkan bahwa terdapat multikolinearitas (Prasanti dkk, 2015).

a. Uji Heterokedastisitas

Heterokedastisitas muncul apabila error dari model yang diamati tidak memiliki varian yang konstan dari suatu pengamatan ke pengamatan lainnya. Salah satunya uji yang digunakan adalah Uji White. Uji White dilakukan dengan meregresikan semua variabel bebas terhadap nilai error kuadratnya. Persamaan yang digunakan pada Uji White sebagai berikut:

$$
\varepsilon_{i}^{2}=\beta+\beta_{1} x_{1}+\beta_{2} x_{2}+\beta_{3} x_{1}{ }^{2}+\beta_{4} x_{2}{ }^{2}+\beta_{5} x_{1} x_{2}+\varepsilon_{i}
$$

b. Uji Autokorelasi

Uji Autokorelasi bertujuan untuk melihat apakah terjadi korelasi antara suatu periode $t$ dengan periode sebelumnya ( $t-1)$. Pengujian untuk mengetahui masalah autokorelasi yang sering digunakan adalah mengunakan metode Durbin-Watson. Hipotesis yang digunakan oleh Durbin-Watson adalah sebagai berikut:

$$
\begin{aligned}
& H_{0}: \rho=0 \text { (tidak ada autokorelasi) } \\
& H_{1}: \rho \neq 0 \text { (ada autokorelasi) }
\end{aligned}
$$

Statistik uji Durbin-Watson dinyatakan pada persamaan sebagai berikut:

$$
d=\frac{\sum_{i=1}^{N} \sum_{t=2}^{T}\left(e_{t}-e_{t-1}\right)^{2}}{\sum_{i=1}^{N} \sum_{t=1}^{n} \theta_{t}^{2}}
$$

Dengan $e_{i t}$ adalah residual unit cross section ke- $i$ waktu ke-j dap adalah koefisien autokorelasi.

Penentuan ada tidaknya autokorelasi dapat dilihat pada Tabel 2.1.

Tabel 1 Uji Statistik Durbin-Watson

\begin{tabular}{cl}
\hline \multicolumn{1}{c}{ Nilai Statistik $\mathrm{d}$} & \multicolumn{1}{c}{ Hasil } \\
\hline $0<d<d_{L}$ & Menolak $H_{0}:$ ada autokorelasi positif \\
$d_{L} \leq d \leq d_{U}$ & Tidak ada keputusan \\
$d_{U} \leq d \leq 4-d_{U}$ & Menerima $H_{0}$ : tidak ada autokorelasi \\
$4-d_{U} \leq d \leq 4-d_{L}$ & Tidak ada keputusan \\
$4-d_{L} \leq d \leq 4$ & Menolak $H_{0}:$ ada autokorelasi negative
\end{tabular}

Apabila jatuh pada daerah tidak ada keputusan, maka digunakan modifikasi uji Durbin-Watson berikut (Gujarati, 2006):

1. $H_{0}: \rho=0 ; \rho>0 . H_{0}$ ditolak pada taraf signifikansi jika $d<d_{U}$

Berarti secara signifikan terdapat autokorelasi positif.

2. $H_{0}: \rho=0 ; \rho<0 . H_{0}$ ditolak pada taraf signifikansi jika $(4-d)<d_{U}$ Berarti secara signifikan terdapat autokorelasi negative.

3. $\quad H_{0}: \rho=0 ; \rho \neq 0 . H_{0}$ ditolak pada taraf signifikanisix jika $d<d_{U}$ atau $(4-d)<d_{U}$.

Berarti secara signifikan terdapat autokorelasi positif atau negatif. 


\subsubsection{Uji Kebaikan Model Regresi Data Panel}

Koefisien determinasi $\left(\mathrm{R}^{2}\right)$ adalah suatu nilai yang menunjukan besarnya perubahan yang terjadi diakibatkan oleh variabel lainnya, koefisien determinasi digunakan untuk mengetahui persentase besarnya keterkaitan antara variabel prediktor terhadap variabel respon (Pambudi, 2013). Persamaan koefisien determinasi $\left(\mathrm{R}^{2}\right)$ sebagai berikut:

$$
\begin{aligned}
R^{2} & =\frac{E S S}{T S S} \\
& =1-\frac{R S S}{T S S} \\
& =1-\frac{\sum \theta_{i}^{2}}{\sum\left(Y_{i}-Y\right)^{2}}
\end{aligned}
$$

Keterangan:

$$
\begin{aligned}
& \text { TSS }=\text { Total Sum of Square } \\
& \text { ESS = Explained Sum of Square } \\
& \text { RSS = Residual Sum of Square }
\end{aligned}
$$

Nilai $\mathrm{R}^{2}$ berkisar antar satu dan nol. Nilai $\mathrm{R}^{2}$ yang kecil berarti kemampuan variabel prediktornya dalam menjelaskan variabel responnya sangat terbatas, begitu pula sebaliknya.

\section{Metode Penelitian}

\subsection{Jenis Penelitian dan Sumber Data}

Pada penelitian ini menggunakan penelitian kuantitatif dimana peneliti mengambil data dari Badan Pusat Statistik Provinsi Sulawesi Selatan.

\subsection{Langkah Analisis}

Adapun tahapan analisis yang akan dilakukan dalam menganalisis studi kasus ini yaitu sebagai berikut:

a. Menganalisis karakteristik untuk variabel respon dan variabel prediktor

b. Menentukan pendugaan parameter pada regresi ganda untuk data panel dengan menggunakan Common Effect Model, Fixed Effect Model, dan Random Effect Model.

c. Menentukan pemilihan model terbaik, dengan cara:

- Melakukan Uji Chow untuk menentukan model terbaik antara Common Effect Model dan Fixed Effect Model, jika yang diperoleh model terbaiknya adalah Common Effect Model maka langkah selanjutnya melakukan uji Lagrange Multiplier, sedangkan jika model terbaiknya adalah Fixed Effect Model maka langkah selanjutnya adalah melakukan Uji Hausman.

- Melakukan Uji Lagrange Multiplier untuk menentukan model terbaik antara Common Effect Model dan Random Effect Model. Jika model terbaiknya adalah Random Effect Model dilanjutkan dengan Uji Hausman..

- Melakukan Uji Hausman untuk menetukan model terbaik antara Fixed Effect Model dan Random Effect Model.

d. Melakukan pengujian signifikansi parameter pada model regresi data panel terbaik, dengan langkah-langkah sebagai berikut:

- Uji Keseluruhan (F)

- Uji Parsial (T)

e. Verifikasi model terhadap model yang terpilih dengan melakukan pengujian asumsi klasik, sebagai berikut:

- Uji Normalitas 
- Uji Multikolinearitas

- Uji Heterokedastisitas

- Uji Autokorelasi

f. Menguji kebaikan model regresi ganda untuk data panel yaitu dengan melihat koefisien determinasi $\left(R^{2}\right)$.

g. Interpretasi hasil

\section{Hasil dan Pembahasan}

\subsection{Hasil Penelitian}

\subsubsection{Kondisi Pertumbuhan Ekonomi Provinsi Sulawesi Selatan}

Tabel 2 Hasil Statistika Deskriptif Pertumbuhan Ekonomi (Y)

\begin{tabular}{lrrrrr}
\hline Deskriptif & \multicolumn{5}{c}{ Pertumbuhan Ekonomi (Y) } \\
& 2013 & 2014 & 2015 & 2016 & Rerata \\
\hline Mean & 7,69 & 7,88 & 7,15 & 7,43 & 7,54 \\
Median & 7,76 & 7,90 & 6,99 & 7,55 & 7,55 \\
Standar Deviasi & 1,07 & 1,32 & 0,94 & 1,61 & 1,23 \\
Min & 5,84 & 4,73 & 5,11 & 1,58 & 4,31 \\
Max & 9,74 & 10,41 & 8,83 & 9,61 & 9,64 \\
\hline
\end{tabular}

Dari Tabel 2, rata-rata pertumbuhan ekonomi Provinsi Sulawesi Selatan pada tahun 2013 hingga 2016 sebesar 7,54 $\%$. Pertumbuhan ekonomi tertinggi terjadi pada tahun 2014 dan terendah terjadi pada tahun 2016.

Tabel 3 Hasil Statistika Deskriptif Pengangguran (X1)

\begin{tabular}{llclll}
\hline Deskriptif & \multicolumn{5}{c}{ Pengangguran (X1) } \\
& 2013 & 2014 & 2015 & 2016 & Rerata \\
\hline Mean & 4,70 & 4,31 & 5,23 & 4,92 & 4,79 \\
Median & 4,57 & 3,05 & 4,61 & 4,54 & 4,46 \\
Standar Deviasi & 2,31 & 2,75 & 2,96 & 2,31 & 2,58 \\
Min & 0,43 & 0,90 & 0,90 & 1,58 & 0,95 \\
Max & 9,53 & 10,9 & 12,07 & 10,96 & 11,02 \\
\hline
\end{tabular}

Dari Tabel 3, rata-rata pengangguran Provinsi Sulawesi Selatan pada tahun 2013 hingga 2016 sebesar $4,79 \%$. Pengangguran tertinggi terjadi pada tahun 2015 dan terendah terjadi pada tahun 2013.

Tabel 4 Hasil Statistika Deskriptif IPM (X2)

\begin{tabular}{llllll}
\hline Deskriptif & \multicolumn{5}{c}{ Indeks Pembangunan Manusia (X2) } \\
& 2013 & 2014 & 2015 & 2016 & Rerata \\
\hline Mean & 66,65 & 67,33 & 67,92 & 68,46 & 67,59 \\
Median & 65,72 & 66,32 & 66,88 & 67,61 & 66,65 \\
Standar Deviasi & 4,35 & 4,29 & 4,31 & 4,23 & 4,28 \\
Min & 60,55 & 61,45 & 61,61 & 61,81 & 61,35 \\
Max & 78,98 & 79,35 & 79,94 & 80,53 & 79,7 \\
\hline
\end{tabular}

Dari Tabel 4, rata-rata indeks pembangunan manusia Provinsi Sulawesi Selatan pada tahun 2013 hingga 2016 sebesar 67,59\%. Indeks pembangunan manusia tertinggi terjadi pada tahun 2016 dan terendah terjadi pada tahun 2013. 
Tabel 5 Hasil Statistika Deskriptif Pendapatan Asli Daerah (X3) (milyar rupiah)

\begin{tabular}{llllll}
\hline Deskriptif & \multicolumn{5}{c}{ Pendapatan Asli Daerah (X3) } \\
& 2013 & 2014 & 2015 & 2016 & Rerata \\
\hline Mean & 74.812 .839 & 106.882 .676 & 120.700 .461 & 146.656 .302 & 112.263 .070 \\
Median & 39.500 .261 & 79.250 .195 & 81.616 .053 & 108.350 .338 & 79.502 .658 \\
Standar Deviasi & $117.877 .378,7$ & $139.260 .846,7$ & $155.952 .340,1$ & $181.008 .448,6$ & $150.194 .674,4$ \\
Min & 16.617 .581 & 8.616 .626 & 33.808 .407 & 34.896 .515 & $23.484 .782,25$ \\
Max & 609.655 .622 & 731.170 .425 & 828.871 .893 & 971.859 .754 & $785.389 .423,5$ \\
\hline
\end{tabular}

Dari Tabel 5, rata-rata pendapatan asli daerah Provinsi Sulawesi Selatan pada tahun 2013 hingga 2016 sebesar 112.263.070 milyar. Pendapatan asli daerah tertinggi terjadi pada tahun 2016 dan terendah terjadi pada tahun 2014.

Tabel 6 Hasil Statistika Deskriptif Pengeluaran Pemerintah (X4) (juta rupiah)

\begin{tabular}{llllll}
\hline Deskriptif & \multicolumn{4}{l}{ Pengeluaran Pemerintah (X4) } & \\
& 2013 & 2014 & 2015 & 2016 & Rerata \\
\hline Mean & 895.234 .784 & 961.914 .806 & 1.133 .015 .540 & 1.424 .061 .755 & 1.117 .157 .950 \\
Median & 745.728 .848 & 877.212 .287 & 1.030 .253 .705 & 1.316 .480 .806 & 1.003 .463 .347 \\
Standar Deviasi & $419.364 .321,2$ & $369.250 .917,9$ & $487.686 .319,7$ & $558.141 .235,6$ & 505620404,6 \\
Min & 578.111 .400 & 612.149 .425 & 742.057 .915 & 894.076 .487 & $706.598 .806,75$ \\
Max & 2.579 .183 .491 & 2.396 .879 .800 & 3.062 .274 .394 & 3.691 .385 .484 & $2.932 .430 .792,25$ \\
\hline
\end{tabular}

Dari Tabel 6, rata-rata pengeluaran pemerintah Provinsi Sulawesi Selatan pada tahun 2013 hingga 2016 sebesar 1.117.157.950 milyar. Pengeluaran pemerintah tertinggi terjadi pada tahun 2016 dan terendah terjadi pada tahun 2013.

Tabel 7 Hasil Statistika Deskriptif Jumlah Penduduk (X5) (jiwa)

\begin{tabular}{llllll}
\hline Deskriptif & \multicolumn{5}{c}{ Jumlah Penduduk (X5) } \\
& 2013 & 2014 & 2015 & 2016 & Rerata \\
\hline Mean & 347.585 .292 & 351.340 .125 & 355.012 .667 & 358.598 .958 & 353.134 .260 \\
Median & 281.948 .500 & 285.186 .000 & 288.346 .500 & 291.481 .500 & 286.758 .000 \\
Standar Deviasi & 271011095.2 & 275042266.6 & 278925944.9 & 282804015.6 & 272603392.7 \\
Min & 127.220 .000 & 128.744 .000 & 130.199 .000 & 131.605 .000 & 129.442 .000 \\
Max & 1.408 .072 .000 & 1.429 .242 .000 & 1.449 .401 .000 & 1.469 .601 .000 & 1.439 .124 .500 \\
\hline
\end{tabular}

Dari Tabel 7, rata-rata jumlah penduduk Provinsi Sulawesi Selatan pada tahun 2013 hingga 2016 sebesar 353.134.260 jiwa. Jumlah penduduk tertinggi terjadi pada tahun 2016 dan terendah terjadi pada tahun 2013.

\subsubsection{Model Regresi Data Panel}

a) Estimasi parameter menggunakan Common Effect Model

Tabel 8 Hasil Estimasi Common Effect Model

\begin{tabular}{lllll}
\hline Variabel & Coefficient & Std. Error & t-statistics & Probability \\
\hline C & $15,83 \times 10^{-1}$ & $3,29 \times 10^{-2}$ & 4,79 & 0,00 \\
X1 & $1,32 \times 10^{-1}$ & $6,65 \times 10^{-2}$ & 1,99 & 0,04 \\
X2 & $-1,29 \times 1,87 \times 10^{-9}$ & $2,72 \times 10^{-9}$ & 0,42 & 0,00 \\
X3 & $1,15 \times 10^{-10}$ & $6,26 \times 10^{-10}$ & $-1,08$ & 0,67 \\
X4 & $-6,79 \times 10^{-10}$ & 6,28 \\
X5 & $1,33 \times 10^{-9}$ & $1,18 \times 10^{-9}$ & 1,13 & 0,26 \\
\hline
\end{tabular}


Dari Tabel 8, hasil estimasi pada common effect model dengan taraf signifikansi $5 \%$ menunjukan terdapat dua variabel yang signifikan berpengaruh terhadap pertumbuhan ekonomi yakni pengangguran dan indeks pembangunan manusia.

b) Estimasi parameter menggunakan Fixed Effect Model

Tabel 9 Hasil Estimasi Fixed Effect Model

\begin{tabular}{lllll} 
Variabel & Coefficient & Std. Error & t-statistics & Probability \\
\hline C & $31,75 \times 10^{-1}$ & $24,83 \times 10^{-2}$ & 1,28 & 0,20 \\
X1 & $1,29 \times 10^{-2}$ & $9,75 \times 10^{-1}$ & 1,33 & 0,18 \\
X2 & $-7,37 \times 3,2 \times 10^{-9}$ & $-0,23$ & 0,81 \\
X3 & $9,45 \times 10^{-9}$ & $6,92 \times 10^{-9}$ & 1,36 & 0,18 \\
X4 & $-5,16 \times 10^{-10}$ & 1,16 & $-0,44$ & 0,66 \\
X5 & $-5,76 \times 10^{-8}$ & $3,93 \times 10^{-8}$ & $-1,47$ & 0,15 \\
\hline
\end{tabular}

Dari Tabel 9, hasil estimasi pada fixed effect model dengan taraf signifikansi $5 \%$ menunjukan hanya terdapat satu variabel yang signifikan berpengaruh terhadap pertumbuhan ekonomi yakni indeks pembangunan manusia.

c) Estimasi parameter menggunakan Random Effect Model

Tabel 10 Hasil Estimasi Random Effect Model

\begin{tabular}{lllll}
\hline Variabel & Coefficient & Std. Error & t-statistics & Probability \\
\hline $\mathrm{C}$ & 15,82 & $3,76 \times 10^{-2}$ & 4,20 & 0,00 \\
$\mathrm{X} 1$ & $1,26 \times 10^{-1}$ & $7,12 \times 18$ & 0,08 \\
$\mathrm{X} 2$ & $-1,29 \times 10^{-1}$ & $5,58 \times 10^{-2}$ & $-2,32$ & 0,02 \\
$\mathrm{X} 3$ & $1,31 \times 10^{-9}$ & $3,03 \times 10^{-9}$ & 0,43 & 0,67 \\
$\mathrm{X} 4$ & $-6,52 \times 10^{-10}$ & $6,25 \times 10^{-10}$ & $-1,04$ & 0,29 \\
$\mathrm{X} 5$ & $1,22 \times 10^{-9}$ & $1,27 \times 10^{-9}$ & 0,96 & 0,34 \\
\hline
\end{tabular}

Dari Tabel 10, hasil estimasi pada common effect model dengan taraf signifikansi $5 \%$ menunjukan hanya terdapat satu variabel yang signifikan berpengaruh terhadap pertumbuhan ekonomi yakni indeks pembangunan manusia.

\subsubsection{Pemilihan Model Regresi Data Panel}

a. Uji Chow (Chow Test)

Tabel 11 Hasil Uji Chow

\begin{tabular}{llll}
\hline Effect Test & Statistics & Df & Probability \\
\hline Cross-section F & 1,35 & 23,67 & 0,17 \\
Cross-section Chi-square & 36,68 & 23 & 0,03 \\
\hline
\end{tabular}

Dari Tabel 11, hasil probabilitas Cross-section Chi-square yaitu sebesar 0,0351. Terlihat bahwa p- value $<\alpha$ $(0,0351<0,05)$, sehingga ditolak. Pada taraf signifikansi $5 \%$ dapat disimpulkan model yang terpilih dalam pengujian ini adalah fixed effect model. 
b. Uji Hausman (Hausman Test)

Tabel 12 Hasil Uji Hausman

\begin{tabular}{llll}
\hline Test Summary & Chi-sq. Statistic & Chi-sq. df. & Probability \\
\hline Cross-section random & 2,81 & 5 & 0,73 \\
\hline
\end{tabular}

Dari Tabel 12, hasil probabilitas Cross-section Chi-square yaitu sebesar 0,73. Terlihat bahwa p- value $>\alpha$ $(0,73>0,05)$, sehingga diterima. Pada taraf signifikansi $5 \%$ dapat disimpulkan bahwa model yang terpilih dalam pengujian ini adalah random effect model.

\subsubsection{Pengujian Signifikansi Parameter}

a. Uji Keseluruhan (Uji F)

Tabel 13 Hasil Uji Keseluruhan (Uji F)

\begin{tabular}{ll}
\hline F-Statistics & Prob(F-statistics) \\
\hline 2,07 & 0,08 \\
\hline
\end{tabular}

Dari Tabel 13didapatkan hasil bahwa besar probabilitas (F-statistics) yaitu sebesar 0,08. Terlihat bahwa p-value $>\alpha$ $(0,08>0,05)$, sehingga diterima. Pada taraf signifikansi $5 \%$ dapat disimpulkan bahwa variabel predictor tidak secara bersama-sama berpengaruh terhadap variabel respon.

b. Uji Parsial (Uji T)

Tabel 14 Hasil Uji Parsil (Uji T)

\begin{tabular}{lllll}
\hline Variabel & Coefficient & Std. Error & t-statistics & Probability \\
\hline C & $15,82 \times 10^{-1}$ & $3,76 \times 10^{-2}$ & 4,20 & 0,00 \\
X1 & $1,27 \times 10^{-1}$ & $7,11 \times 10^{-2}$ & 1,78 & 0,08 \\
X2 & $-1,29 \times 1,58 \times 10^{-9}$ & $3,03 \times 10^{-9}$ & 0,43 & 0,02 \\
X3 & $1,31 \times 10^{-10}$ & $6,25 \times 10^{-10}$ & $-1,04$ & 0,29 \\
X4 & $-6,52 \times 10^{-10}$ & $1,27 \times 10^{-9}$ & 0,96 & 0,34 \\
X5 & $1,22 \times 10^{-9}$ & & &
\end{tabular}

Dari Tabel 14 didapatkan hasil bahwa hanya indeks pembangunan manusia (X2) yang memiliki nilai probabilitas lebih kecil dari 0,05. Sehingga pada taraf signifikansi 5\% dapat disimpulkan bahwa indeks pembangunan manusia berpengaruh secara signifikan terhadap pertumbuhan ekonomi, sedangkan pengangguran, pendapatan asli daerah, pengeluaran pemerintah dan jumlah penduduk tidak berpengaruh secara signifikan terhadap pertumbuhan ekonomi.

\subsubsection{Pengujian Asumsi Klasik Terhadap Model yang Terpilih}

a. Uji Normalitas

Tabel 15 Hasil Uji Normalitas

\begin{tabular}{ll}
\hline Kolmogorov Smirnov & p-value \\
\hline 1,1906 & 0,200 \\
\hline
\end{tabular}

Dari Tabel 15 dapat dilihat nilai probability sebesar 0,200 . Terlihat p-value $<\alpha(0,200<0,05)$ sehingga ditolak. Pada taraf signifikansi $5 \%$ dapat disimpulkan bahwa data berdistribusi normal. 
b. Uji Multikolinearitas

Tabel 16 Hasil Uji Multikolinearitas

\begin{tabular}{ll}
\hline Variabel & VIF \\
\hline Pengangguran & 1,69 \\
Indeks Pembangunan Manusia & 2,56 \\
Pendapatan Asli Daerah & 9,51 \\
Pengeluaran Pemerintah & 4,83 \\
Jumlah Penduduk & 5,33 \\
\hline
\end{tabular}

Berdasarkan Tabel 16, masing-masing variabel prediktor mempunyai nilai $\operatorname{VIF}<10$, sehingga dapat disimpulkan bahwa tidak terdapat multikolinearitas.

c. Uji Heterokedastisitas

Tabel 17 Hasil Uji Heterokedastisitas

\begin{tabular}{cll}
\hline Breusch-Pagan & Df & p-value \\
\hline 4,7408 & 5 & 0,4483 \\
\hline
\end{tabular}

Dari Tabel 17 dapat dilihat $p$-value sebesar 0,4483, terlihat bahwa p-value $>\alpha(0,4483>\alpha)$ sehingga diterima. Pada taraf signifikansi $5 \%$ dapat disimpulkan bahwa tidak terdapat heterodastisitas.

d. Uji Autokorelasi

Tabel 18 Hasil Uji Autokorelasi

\begin{tabular}{lll}
\hline Durbin-Watson & Df & p-value \\
\hline 1,794 & 5 & 0,1038 \\
\hline
\end{tabular}

Dari Tabel 18 dapat dilihat nilai probability sebesar 0,1038 , terlihat bahwa p-value $>\alpha(0,1038>\alpha)$ sehingga diterima. Pada taraf signifikansi 5\% dapat disimpulkan bahwa tidak terdapat autokorelasi.

\subsubsection{Kebaikan Model Regresi Data Panel}

Dari hasil estimasi didapatkan bahwa koefisien determinasi (R-squared) sebesar 0,103. Artinya variabel prediktor hanya mampu menjelaskan variabel respon sebesar 10,3\% sedangkan sisanya sebesar 89,7\% dijelaskan oleh variabel lain diluar model.

\subsection{Pembahasan}

Berdasarkan pengujian yang telah dilakukan diperoleh model akhir regresi untuk data panel untuk pertumbuhan ekonomi Provinsi Sulawesi Selatan yaitu random effect model sebagai berikut:

$$
Y_{\text {it }}=15,819+0,1268 X_{1}-0,1294 X_{2}+1,31 X_{3}-0,652 X_{4}++0,00122 X_{5}
$$

Hubungan antara masing-masing variabel prediktor terhadap variable respon dilihat dari koefisien. Hasilnya sebagai berikut:

a) Variabel Pengangguran (X1)

Koefisien variabel pengangguran sebesar 0,1268 artinya ketika pengangguran meningkat satu-satuan maka pertumbuhan ekonomi juga akan meningkat sebesar 0,1268\% pertahunnya, dengan koefisien variabel lainnya dianggap konstan. Dan probabilitas t-statistik sebesar 0,08, sehingga pada taraf signifikansi 5\% dapat disimpulkan 
bahwa pengangguran memiliki hubungan positif namun tidak berpengaruh signifikan terhadap pertumbuhan ekonomi.

b) Variabel Indeks Pembangunan Manusia (X2)

Koefisien variabel indeks pembangunan manusia sebesar -0,1294 artinya ketika indeks pembangunan manusia meningkat satu-satuan maka pertumbuhan ekonomi akan menurun sebesar 0,1294 \% pertahunnya, dengan koefisien variabel lainnya dianggap konstan. Dan probabilitas t-statistik sebesar 0,02, sehingga pada taraf signifikansi 5\% dapat disimpulkan bahwa indeks pembangunan manusia memiliki hubungan negatif namun berpengaruh signifikan terhadap pertumbuhan ekonomi. Penelitian ini mendukung hasil penelitian yang telah dilakukan oleh Muqorrobin dan Soejoto (2017) yang menunjukkan bahwa indeks pembangunan manusia memiliki hubungan negatif namun signifikan berpengaruh terhadap pertumbuhan ekonomi.

c) Variabel Pendapatan Asli Daerah (X3)

Koefisien variabel pendapatan asli daerah sebesar 1,31 artinya ketika pendapatan asli daerah meningkat 1 milyar maka pertumbuhan ekonomi akan ikut meningkat sebesar 1,31\% pertahunnya, dengan koefisien variabel lainnya dianggap konstan. Dan probabilitas t-statistik sebesar 0,67, sehingga pada taraf signifikansi 5\% dapat disimpulkan bahwa pendapatan asli daerah tidak berpengaruh signifikan terhadap pertumbuhan ekonomi. Penelitian ini bertolakbelakang dengan hasil penelitian yang telah dilakukan oleh Suherlan (2017) yang menunjukkan bahwa pendapatan asli daerah berpengaruh signifikan dan positif terhadap pertumbuhan ekonomi di Kabupaten/Kota di Provinsi Jawa Barat. Hal ini kemungkinan disebabkan oleh penerimaan daerah dari PAD yang tidak begitu optimal karena penerimaan pajak dan retribusi daerah tidak maksimal dikumpulkan oleh pemerintah daerah Sulawesi Selatan atau dikarenakan terjadinya ketimpangan penerimaan PAD antar Kabupaten/Kota di Sulawesi Selatan, terdapat daerah yang memliki penerimaan PAD sangat tinggi namun juga terdapat daerah yang memiliki penerimaan PAD yang rendah.

d) Variabel Pengeluaran Pemerintah (X4)

Koefisien variabel pengeluaran pemerintah sebesar -0,652 artinya ketika pendapatan asli daerah meningkat 1 milyar maka pertumbuhan ekonomi akan menurun sebesar $0,652 \%$ pertahunnya, dengan koefisien variabel lainnya dianggap konstan Dan probabilitas t-statistik sebesar 0,29, sehingga pada taraf signifikansi 5\% dapat disimpulkan bahwa pendapatan asli daerah memiliki hubungan negatif dan tidak berpengaruh signifikan terhadap pertumbuhan ekonomi. Penelitian ini mendukung hasil penelitian yag telah dilakukan oleh Rahman dan Ayunda (2015) yang menunjukkan bahwa pengeluaran pemerintah memiliki hubungan positif namun tidak berpengaruh signifikan terhadap PDRB Kab/Kota di Jawa Tengah. Hasil tersebut tidak sesuai dengan teori yang mengatakan bahwa peningkatan belanja daerah/pengeluaran pemerintah akan meningkatkan PDRB berarti terjadi pertumbuhan ekonomi karena pertumbuhan ekonomi diukur dari perubahan PDRB. Pengaruh tidak signifikannya antara pengeluaran pemerintah terhadap pertumbuhan ekonomi di Sulawesi Selatan diharapkan peranan pemerintah dalam mengelola pengeluaran pemerintah untuk menyediakan infrastruktur bagi sektor swasta mengingat kemampuan sektor swasta dalam mendorong pertumbuhan ekonomi sangat terbatas sehinga peranan pemerintah sangat penting.

e) Variabel Jumlah Penduduk (X5)

Koefisien variabel jumlah penduduk sebesar 0,00122 artinya ketika jumlah penduduk meningkat 1 juta jiwa maka pertumbuhan ekonomi akan ikut meningkat sebesar 0, 00122\% pertahunnya, dengan koefisien variabel lainnya dianggap konstan. Dan probabilitas t-statistik sebesar 0,34, sehingga pada taraf signifikansi 5\% dapat disimpulkan bahwa jumlah penduduk memiliki hubungan positif namun tidak berpengaruh signifikan terhadap pertumbuhan ekonomi. Penelitian ini bertolakbelakang dengan hasil penelitian yang telah dilakukan oleh Adinda dan Deden (2018) yang menunjukkan bahwa jumlah penduduk memiliki hubungan positif dan berpengaruh signifikan terhadap pertumbuhan ekonomi di Kabupaten/Kota di Provinsi Jawa Tengah.

\section{Kesimpulan}

Berdasarkan hasil analisis dan pembahasan pada bab IV, maka diperoleh beberapa kesimpulan sebagai berikut: 
- Model regresi data panel yang terbaik dan sesuai untuk pemodelan pertumbuhan ekonomi Provinsi Sulawesi Selatan dari tahun 2013 sampai dengan 2016 adalah random effect mode, dengan model persamaan hasil estimasi sebagai berikut:

$$
Y_{i t}=15,819+0,1268 X_{1}-0,1294 X_{2}+1,31 X_{3}-0,652 X_{4}++0,00122 X_{5}
$$

- R2 Diperoleh sebesar 10,3\% berarti variabel pengangguran, indeks pembangunan manusia, pendapatan asli daerah, pengeluaran pemerintah, jumlah penduduk tidak mampu menjelaskan variabel pertumbuhan ekonomi sedangkan sisanya sebesar 89,7\% dijelaskan oleh variabel lain diluar model. Dan pada taraf signifikansi 5\% hanya variabel indeks pembangunan manusia yang signifikan berpegaruh terhadap pertumbuhan ekonomi.

\section{References}

Apriliawan, D. T. \& Hasbi Yasin. (2013). Pemodelan Laju Inflasi di Provinsi Jawa Tengah Menggunakan Regresi Data Panel. Jurnal Gaussian.

Baltagi, B.H., (2015). Econometric Analysis of Panel Data. Edisi Ketiga. Library of Congress Cataloging in Publication Data. British.

BPS Provinsi Sulawesi Selatan, Sulawesi Selatan dalam Angka 2016.

BPS Provinsi Sulawesi Selatan, Sulawesi Selatan dalam Angka 2017.

BPS Provinsi Sulawesi Selatan, Statistik Keuangan Daerah Pemerintah Kabupaten/Kota Provinsi Sulawesi Selatan 2013/2014.

BPS Provinsi Sulawesi Selatan, Statistik Keuangan Daerah Pemerintah Kabupaten/Kota Provinsi Sulawesi Selatan 2015/2016.

Dumairy, (1996). Perekonomian Indonesia. Jakarta: Erlangga.

Gujarati, D. N. (2004). Basic Econometrics. Mc Graw-Hill Inc: Upper Saddle River, New Jersey.

Hapsari, A. P. \& Deden Dinar. (2018). Faktor-Faktor yang Mempengaruhi Pertumbuhan Ekonomi Provinsi Jawa Tengah Periode 2010-2014. JIEP

Ibnurasyad, Z. (2016). Analisis pengaruh investasi, tenaga kerja, jumlah penduduk, dan pengeluaran pemerintah terhadap pertumbuhan ekonomi provinsi Daerah Istimewa Yogyakarta tahun 2004-2014. Skripsi Universitas Negeri Sunan Kalijaga.

Jirata, M. T. (2014). Estimation of Panel Data Regression Model with Individuaal Effects. Pan African Unicersity.

Kuncoro, M., (2011). Metode Kuantitatif: Teori dan Aplikasi untuk Bisnis dan Ekonomi. Edisi Pertama, UPP AMP YKPN, Yogyakarta.

Muqorrobin dan Soejoto (2017). Pengaruh Indeks Pembangunan Manusia (IPM Terhadap Pertumbuhan Ekonomi Provinsi Jawa Timur. Jurnal Pendidikan Ekonomi.

Nachrowi, D. N. dan H. Usman. 2006. Pendekatan Populer dan Praktis Ekonometrika Untuk Analisis Ekonomi dan Keuangan. Jakarta: Lembaga Penerbit FE UI.

Pambudi, E. W. dan Miyasto. (2013). Analisis Pertumbuhan Ekonomi dan Faktor-Faktor yang Mempengaruhi Kabupaten/Kota di Provinsi Jawa Tengah. Diponegoro Journal of Economics.

Pangestika, S. (2015). Analisis Estimasi Model Regresi Data Panel dengan Pendekatan Common Effect Model, Fixed Effect Model, Random Effect Model. Skripsi Universitas Negeri Makassar.

Prasanti, T. A, Triastuti, W, \& Agus, R. (2015). Aplikasi Regresi Data Panel untuk Pemodelan Tingkat Pengangguran Terbuka Kabupaten/Kota di Provinsi Jawa Tengah. Jurnal Gaussian.

Rahmadeni, dan Nindya, W. (2017). Analisis Faktor-Faktor yang Mempengaruhi Inflasi pada Kota Metropolitan di Indonesia dengan Menggunakan Analisis Data Panel. Jurnal Sains Matematika dan Statistika, 34-42. 
Rahman, Y. A. dan Ayunda, L. C. (2015). Faktor-Faktor yang Mempengaruhi PDRB Kabupaten/Kota Jawa Tengah Tahun 2008-2012. Journal of Economics and Policy. 88-99.

Rizki, N. A (2011). Estimasi Parameter Model Regresi Data Panel Random Effect dengan Metode Generalized Least Square (GLS). Skripsi Universitas Islam Negeri Maulana Malik Ibrahim Malang.

Sodik, J. (2007). Pengeluaran Pemerintah dan Pertumbuhan Ekonomi Regional: Studi Kasus Data Panel di Indonesia.

Jurnal Ekonomi Pembangunan Kajian Ekonomi Negara Berkembang.

Sukirno, S. (2004). Makro Ekonomi Teori Pengantar, Edisi 3. PT. Raja Grafindo Persada: Jakarta.

Susanti, S. (2013). Pengaruh Domestik Regional Bruto, Pengangguran dan Indeks Pembangunan Manusia Terhadap Kemiskinan di Jawa Barat dengan Menggunakan Analisis Data Panel. Jurnal Matematika Integratif, 1-18.

Suherlan, H. (2017). Faktor-Faktor yang Mempengaruhi Pertumbuhan Ekonomi Kabupaten/Kota di Provinsi Jawa Barat. Tourism Scientific Journal, 18-27. 